\title{
Freedom Narratives: The West African Person as the Central Focus for a Digital Humanities Database
}

\author{
Érika Melek Delgado* $\odot$
}

Department of Spanish, Portuguese, and Latin American Studies, King's College, London WC2R 2LS, United Kingdom

*Corresponding author. E-mail: erika.melek_delgado@kcl.ac.uk

\begin{abstract}
This article discusses the methodology behind the development of new tools of research for African history that are a user-friendly source for public engagement. The focus is on biographical profiles of West African people during the era of the transAtlantic slave trade, which is an innovative approach to social history. The representation of enslaved Africans has typically been numbers recorded in logs and accounts compiled by slave merchants and captains. Freedom Narratives is an open-source relational database that reveals the people who constitute those numbers.
\end{abstract}

Résumé: Cet article discute de la méthodologie se situant derrière le développement de nouveaux outils de recherche pour l'histoire africaine, des outils qui sont une source facile d'utilisation pour interagir avec le grand public. L'accent est mis sur les profils biographiques de personnes d'Afrique de l'Ouest à l'époque de la traite esclavagiste transatlantique, ce qui constitue une approche innovante en histoire

History in Africa, Volume 48 (2021), pp. 35-59

Érika Melek Delgado is a Leverhulme Early Career Fellow at King's College London. She is the principal investigator of the project Historical African Childhoods (HAC Project), as well as director of Freedom Narratives and of the web-development company Walk With Web. For her Early Career Fellow position, Érika was approved for the Leverhulme Trust and the British Academy fellowships. Prior to her current position, she completed a two-year Postdoctoral Fellowship at the Harriet Tubman Institute for Research on Africa and its Diasporas at York University, Canada. As a postdoc fellow, she was awarded two major grants from the Andrew W. Mellon Foundation and the Social Sciences and Humanities Research Council (SSHRC) of Canada.

(c) The Author(s), 2022. Published by Cambridge University Press on behalf of the African Studies Association. This is an Open Access article, distributed under the terms of the Creative Commons Attribution licence (https://creativecommons.org/ licenses/by/4.0/), which permits unrestricted re-use, distribution, and reproduction in any medium, provided the original work is properly cited.

doi:10.1017/hia.2021.14 
sociale. La représentation des Africains réduits en esclavage a généralement été sous la forme de nombres enregistrés dans des journaux et des comptes compilés par les marchands d'esclaves et des capitaines de navire. Freedom Narratives est une base de données relationnelle open source qui révèle les personnes qui constituent ces nombres.

\section{Introduction}

Freedom Narratives (www.freedomnarratives.org) is a digital humanities project with an aim to create a digital repository of biographical accounts of individuals born in West Africa from the sixteenth to the nineteenth centuries. ${ }^{1}$ The emphasis of this research is on the testimony of those who may be considered as "Atlantic Africans" or who experienced slavery or might have ended up in the transatlantic trade. Although this project's primary attempts are to recover the voices of those who were somehow involved in the Atlantic or internal slave trade, it is not restricted to people who experienced enslavement. Individuals who travelled within and from West Africa as well as those who experienced the "Middle Passage" are included in this biographical/ prosopographical digital repository. The Atlantic crossing is often considered a defining moment in the slavery experience, but individuals did not only cross the Atlantic. They might have experienced similar lengthy journeys across the Sahara or within Africa via caravans and by sea to Sierra Leone, for instance. $^{2}$

African identities and trajectories are the heart of this project. Unlike other databases for the study of Africa, diaspora, and transatlantic history, the focus is on people, as is the case with other relevant prosopographical projects on different areas of the world. ${ }^{3}$ More precisely, this project focuses on people who were born in West Africa during the period of the transatlantic slave trade and who, in large measure, were once enslaved but often free at birth. This project shifts from a quantitative perspective to a narrower focus on the question, "Who were these individuals?" It aims to bring real-life experiences and "faces" to some of the more than 12.5 million human lives who experienced the traumatic reality of the transatlantic slave trade.

${ }^{1}$ I wish to thank Paul E. Lovejoy, Kartikay Chadha, Lorelle Semley, Bethan Mobey, and those who agreed to participate in the peer-review process. Freedom Narratives has been made possible because of financial support from the Social Sciences and Humanities Research Council of Canada, the Andrew W. Mellon Foundation, and the Leverhulme Trust.

2 Pier M. Larson, "Horrid Journeying: Narratives of Enslavement and the Global African Diaspora," Journal of World History 19-4 (2008), 441.

3 Two important databases that deal with Chinese and European populations are China Biographical Database Project (CBDB), https://projects.iq.harvard.edu/ cbdb/prosopography (accessed 5 June 2021), and Unit for Prosopographical Research, http://users.ox.ac.uk/ prosop/ (accessed 5 June 2021). 


\section{Digital Identities: Life as the Central Focus}

Freedom Narratives is motivated by the research on biographical data from West Africa by Paul E. Lovejoy that culminated in several projects. ${ }^{4}$ The term "freedom narratives" reconceptualizes the traditional "slave narrative" by emphasizing those who were born free and who, in many cases, died free after their enslavement. The shift in focus from slavery to freedom in the analysis of biographies provides the founding principle of the methodological approach for this project. ${ }^{5}$ The accounts based on the concept of "freedom narratives," according to Lovejoy, recount the experience of natal alienation and direct exposure to the Middle Passage, as opposed to subjugation at birth and the memory of the Middle Passage and what had been retained about the homeland. Atlantic Africans born in Africa who were enslaved had a unique experience from those born in the diaspora. ${ }^{6}$ They faced the uncertain future of the Middle Passage, while those born in the Americas did not, even if individuals were sometimes transferred over considerable distances in the Americas. For the Freedom Narratives project, this concept has been expanded to all accounts produced historically and for historical narratives consequent of academic research, including both autobiographies and biographical reconstructions.

"Freedom narratives" are about recounting the hope of being reunited with kin or members of their societies, something that was more difficult and often impossible in the transatlantic and trans-Saharan diasporas. ${ }^{7}$ For a comparative perspective, this project assumes that the experience of slavery

4 Paul E. Lovejoy, "The African Background of Venture Smith," in Stewart, James B. (ed.), Venture Smith and the Business of Slavery and Freedom (Amherst: University of Massachusetts Press, 2009), 35-55; Paul E. Lovejoy, "Autobiography and Memory: Gustavus Vassa and the Abolition of the Slave Trade," Slavery and Abolition 27-3 (2006), 317-347; Yacine Daddi Addoun and Paul E. Lovejoy,"The Arabic Manuscript of Muhammad Kaba Saghanughu of Jamaica, c. 1820,” in Paul, Annie (ed.), Creole Concerns: Essays in Honour of Kamau Brathwaite (Kingston: University of the West Indies Press, 2007), 313-341; Paul E. Lovejoy, "Les origines de Catherine Mulgrave Zimmermann: considérations méthodologiques," Cahiers des Anneaux de la Mémoire 14 (2011), 247-263; Robin Law and Paul E. Lovejoy, The Biography of Mahommah Gardo Baquaqua: His Passage from Slavery to Freedom in Africa and America (Princeton: Markus Wiener Publisher, 2001); Paul E. Lovejoy, "Ali Eisami's Enslavement and Emancipation: The Trajectory of a Liberated African," in Anderson, Richard and Lovejoy, Henry B. (eds.), Liberated Africans and the Abolition of the Slave Trade, 1807-1896 (Rochester: University of Rochester Press, 2020); Paul E. Lovejoy, “Mohammed Ali Nicholas Sa'id: From Enslavement to American Civil War Veteran,” Millars (2017), 219-232.

5 Paul E. Lovejoy, "Freedom Narratives of Transatlantic Slavery," Slavery and Abolition 32-1 (2011), 91.

6 Larson, "Horrid Journeying," 431-464.

7 Érika Melek Delgado, Kartikay Chadha, Paul E. Lovejoy, "Freedom Narratives of West Africans from the Era of Slavery,” in Lovejoy, Paul E., Lovejoy, Henry B., 
for those who were subjected to it for an isolated stage of their life was distinct from those who were born into slavery (in the diaspora and elsewhere) and who thus grew up in slave societies from birth.

The focus on African-born people also relates to the lack of personal information on people born in Africa during the intense period of the transatlantic slave trade. Important projects and research (digital and analogue) have mostly concentrated on uncovering life information of people who were born in the diaspora. One of the reasons for this is the belief that it is difficult to find enough sources to reveal life stories of people who began their stories far from where they lived the large part of their lives under enslavement. The natal alienation of those people has been seen by several historians as prohibitive to the recovery of their life narratives. ${ }^{8}$ In most cases of the surviving accounts from people born in West Africa, a significant number are from individuals who were born free and managed to reclaim their freedom at a stage of their lives. The experience of slavery was therefore only an aspect, even if an important one, of their personal experiences.

Individuals who never experienced enslavement are also included in the database with the intention of recording a diversity of life stories of West Africans who were based in areas where their lives were significantly influenced by the internal and/or Atlantic slave trades. Moreover, this project identifies and documents various types and categories of relationships experienced by the person whose information is entered in the database. Kinship, friendship, and other types of relationships are recorded, and, consequently, it is now possible to navigate and explore more information on related individuals.

Different sources will recount distinct experiences of someone's life. As an example, a large part of Freedom Narratives digital identities come from sources related to Liberated Africans around the Atlantic, which accounts for approximately 250,000 people. ${ }^{9}$ The main source is the Registers of Liberated Africans. These documents, produced by the international mixed commission courts, recorded personal information of each enslaved African captured and liberated under their jurisdiction. The documents, produced mainly in Sierra Leone, Brazil, Cuba, and Saint Helena, recorded names, often including names classified as "African names" based on what clerks understood from interpreters. ${ }^{10}$ However, for cases in Brazil, most records used Christian names, as Portuguese/Brazilian slave traders baptized all

Chadha, Kartikay, and Melek Delgado, Érika (eds.), Regenerated Identities - Documenting African Lives (Trenton: Africa World Press, 2021).

8 Larson, "Horrid Journeying," 434.

9 Henry B. Lovejoy (dir.), Liberated Africans, http://liberatedafricans.org/ (accessed 5 June 2021).

${ }^{10}$ Henry B. Lovejoy, "The Register of Liberated Africans of the Havana Slave Trade Commission: Transcription Methodology and Statistical Analysis," African Economic History 38 (2010), 116; Suzanne Schwarz, "Reconstructing the Life Histories 
enslaved people prior to or just after disembarkation in the Americas. Additional information on physical description, gender, age, "nation," and locations for each person allows the creation of biographical data that can be correlated with information from other sources.

The project does not limit itself to a specific type of source. The variety of data analyzed is vast, encompassing autobiographies, interviews, sketches, runaway advertisements, ship logs, colonial administrative books, court papers, registers of baptism, marriage, and death, and so on. Its aim is to allow an investigation through biographical narratives, whether the sources come from a personal testimony, for instance, or a Register of Liberated Africans taken off slave ships. Each source can be interpreted depending on whether the primary texts arise from first-person memory or amanuensis, or if the administrative sources are a third-person interpretation with power over the person recorded.

Not only can individual life stories be uncovered, but also family stories. One such example is the case of a Fon-speaking family who arrived in Freetown, Sierra Leone, in 1827 aboard the Portuguese/Brazilian vessel Conceição de Maria, which came from Bahia and embarked the family at Ouidah. ${ }^{11}$ The identification of an ethnonym/language can be achieved based on different methods, and more will be explained further in the article. In the case of this family, the document does not mention any "nation," yet the identification is based on the names recorded as well as the area where the family embarked on the slave vessel. As it is impossible to guarantee the ethnonym classification since it was not recorded in the document, this specific data is classified on the website as imputed by the author. The mother, Dada, arrived in Freetown after more than a month at sea. Personal records about this family were found in three different documents held in archives in Sierra Leone and in the UK. ${ }^{12}$ These documents were not replicas, despite the similarity of information and the data in the registers. Dada was described in one of the registers as 20 years old, and 31 years old in another. Each age estimate was recorded by a different clerk. She was also described with scarification on her temple. ${ }^{13}$ Dada - or Daday as her name appeared in one of the documents - was the mother of a baby boy, identified as one year old or 16 months, who survived these dreadful experiences in his first months

of Liberated Africans: Sierra Leone in the Early Nineteenth Century," History in Africa 39 (2012), 176-177.

11 David Eltis et al., Voyages: The Trans-Atlantic Slave Trade Database, Voyage ID: 2977 https:/ / www.slavevoyages.org/voyage/2977/variablesç (accessed 5 June 2021). I wish to thank Lorelle Semley for identifying the names as Fon.

12 Sierra Leone Public Archives, Register of Liberated Africans, 1827-1829 25,423-30,708: Register Nos. 25,454; 35,454; 25,501; The National Archives, Foreign Office 315/31, Slaves Emancipated, 1829-1828, Register Nos. 10,718; 10,762; 10,763.

13 This specific vessel had nine women with their children, though this number of families on board slave vessels was uncommon. 
of life. His name is unknown. The other person on board the vessel, who is also identified as her son, was called Bosseo or Bosoo. He was 11 or 13 years old and 4 feet 11 inches. ${ }^{14}$ They disembarked in Freetown on 15 May 1827. Given the age differences and the fact that "dada" could be translated as "older sister," it may be possible that Dada and Bosseo were siblings, mother and son, or otherwise related. In one of the registers, it is written that he was her child. ${ }^{15}$

Before boarding the ship in Ouidah, Bosseo experienced one of the worst acts of slavery - branding. He and most of the children who were aboard this vessel were marked with the symbol of a heart on their left arm. Bosseo was also described as having cuts on his forehead and cheeks. It is probable that Dada and Bosseo would have had their life paths separated upon arrival in Brazil, as Dada did not have her body branded with a hot iron, which means her owner was probably someone else. Other sources demonstrate that there was no mercy for pregnant women or new mothers as they were branded before embarkation, some even on their breasts when they likely were still breastfeeding. ${ }^{16}$ After her arrival in Sierra Leone, Dada followed the rules at the time and left the Kings Yard (the harbor area where all Liberated Africans were confined after disembarkation) just after a man chose her to marry. His name was Henry Frank, and he was a Liberated African. She moved to his house in Freetown with the two children. ${ }^{17}$

Different from most of the Liberated African children who arrived in Sierra Leone, Bosseo was not apprenticed, at least not immediately after his arrival. This is because Bosseo had a family, and he was their responsibility. However, this was not the fate of most Liberated African children. ${ }^{18}$ After their arrival in the colony, children were usually classified as "liberated"

${ }^{14}$ For a discussion of the relationship of height and age classification for Liberated Africans, see Érika Melek Delgado, "Liberated African 'Children' in Sierra Leone: Colonial Classifications of 'Child' and 'Childhood,' 1808-1819," in Anderson, Richard, and Lovejoy, Henry B. (eds.), Liberated Africans and the Abolition of the Slave Trade, 1807-1896 (Rochester: University of Rochester Press, 2020), 81-100; Érika Melek Delgado, "Children, Childhood and Slavery in Sierra Leone: The Experiences of Liberated African Children, c.1808-1834" (unpublished PhD Thesis, University of Worcester, 2018).

15 SLPA, RLA, 1827-1829 25.423-30.708, Register No. 25,501.

16 Melek Delgado, "Children, Childhood and Slavery," 134.

17 SLPA, RLA, 1827-1829 25.423-30.708, Register No. 25,454; 35,454; 25,501; SLPA, Liberated African Department Statement of Disposal 1821-1833, vessel: Conceição de Maria.

18 Melek Delgado, "Liberated African 'Children' in Sierra Leone," 81-100. For more about the influence of the "disposal" on Liberated Africans' lives, see Suzanne Schwarz, "The Impact of Liberated Africans 'Disposal' Policies in Early NineteenthCentury Sierra Leone," in Anderson, Richard and Lovejoy, Henry B. (eds.), Liberated Africans and the Abolition of the Slave Trade, 1807-1896 (Rochester: University of Rochester Press, 2020), 45-65. 
rather than "free" and obliged to work for approximately 14 years; they were often assigned to several masters who paid the colonial administration for their labor. These different events and social statuses, specifically the distinction between "free" and "liberated," are clearly identified on the website. This family narrative is not complete. However, there is enough data, some not recorded in this short description, to include this family as part of the database. Further information is being searched for each of these individuals because the project is interested in the development of the family itself. As stated earlier and demonstrated in the above example, the aim of this project is to capture life movements, and a person is only included in the database when concrete evidence is identified to prove their existence and actions. This is not a project on names, but on lives.

\section{A Digital Humanities Project - Not a Digital Archive}

Every person acts as an anchor in the Freedom Narratives database, and all the other data fields are connected through them. Freedom Narratives has led to the development of an interactive, complex computational and interpretational database that records life experiences of West African people. This project seeks to provide a user-friendly experience and opportunities for holistic engagement with the website for both the general public and academic audiences. A large amount of data is collected in diverse formats (including printed and digital sources as well as databases), which is then analyzed and organized using the Decoding Origins Web Portal (henceforth called Web Portal) for the entry of every individual life narrative. ${ }^{19}$ In this process, thousands of primary sources are analyzed and stored, and hundreds of others are being digitized. All these data are backed up using cloud computing services and uploaded to the Web Portal, where it is meta tagged and connected to the individuals' profiles and other related sources. As Digital Humanities academics have highlighted, the creation of bigger data sets can be a challenge in the field of history, as the creation of large sets of data requires the constant development of new tools. ${ }^{20}$ Freedom Narratives is a Digital Humanities project, which is a large umbrella with diverse tools used to establish the digital identities of people. ${ }^{21}$ Rather than existing solely as a database, the project aims to record life experiences. Therefore, it provides visual representation through GIS mapping of event locations, a listing of variant spellings for ethnonyms/languages, access to digital copies of rare sources, and a short historical narrative created for each digital identity.

19 Kartikay Chadha, Katrina Keefer, and Martha Ladly, Decoding Origins Web Portal, http:/ / www.decodingoriginswebportal.org/ (accessed 5 June 2021).

${ }^{20}$ Snickars Pelle, "Himalaya of Data," International Journal of Communication 8 (2014).

21 Matthew K. Gold and Lauren F. Klein, Debates in the Digital Humanities 2016 (Minneapolis: University of Minnesota Press, 2016). 
According to Gerben Zaagsma though, the real challenge faced by history and its projects is to be consciously hybrid. Zaagsma claims that a hybrid approach necessitates the integration of "traditional" and "digital" approaches in a new practice of history. ${ }^{22}$ Zaagsma also argues for the nonexistence of a discipline called "Digital History," as we no longer live in a world that is completely analogue, and history has become digital, as has every other aspect of our lives. For him, "Digital History" is a transitional term, which exists to help to "emphasise and put into focus new practices, whether in terms of analysis or knowledge (re)presentation or both; and it highlights how data and tools are changing historical knowledge production."23

While we have developed best practices for searching, digitizing, and meta tagging sources, our aim is not to be a digital archive. As Kate Theimer argues, the term "digital archive" has been wrongly used to name any collection organized digitally. According to Theimer, the efforts to demonstrate the distinction between an archive and digital preservation would encourage "more rigorous assessment of digital historical representations and will result in a greater understanding and appreciation of what makes archives distinct from these other kinds of products." For her, the other projects can be described by the umbrella term "Digital Historical Representations," which cover resources presented by archives but also other digital humanities outputs, separating "intellectual products created from archival sources." 24 Theimer's arguments are significant in how Freedom Narratives' digital compilations of sources have been orientated, as the majority come from physical archives, even if they have already been digitized to be made accessible. Our source compilation and meta tagging orient the project into considerations of how to prioritize sources related to its themes. The website is not an archive; therefore, there is no intention to have complete source collections, if only one source is relevant. Nevertheless, strict best practices govern the collection and compilation of the sources on the website.

The Freedom Narratives public website is the front interactive interface for the open-source relational database, showcasing digital copies of original documentation in PDF format with metadata organized into data fields. The project deals with the challenges of big data and primarily employs the hybrid methodology. The analysis of data is done by combining restricted historical methods with the digital tools for the organization of data, visual presentation, and connection of distinct results for the production of secondary sources such as maps, graphs, teaching materials, and mainly the biographies

22 Gerben Zaagsma, "On Digital History,” BMGH - Low Countries Historical Review 128 (2013), 15.

${ }^{23}$ Zaagsma, "On Digital History," 4.

24 Kate Theimer, "A Distinction Worth Exploring: 'Archives' and 'Digital Historical Representation,'” Journal of Digital Humanities 2-3 (2014). 
themselves. ${ }^{25}$ The intention is to enable analysis at both the macro and micro levels of the historical tragedy and crime against humanity that affected the history of Africa and was responsible for the demographic, cultural, and social transformation of the Americas and elsewhere. The database produces secondary sources through constructed historical narratives and facilitates access to all documentation through the public website. The project allows the analysis not only of patterns in the slave trade but especially of the life experiences of slavery and freedom, particularly in terms of where profiled individuals originated from, why they were enslaved, what happened to them, and thereby enables reflections on ethnonym, language, and names.

The creation of a digital database involves working with a team that primarily consists of historians, visual designers, and computer programmers, including website and database developers. The members of the team and collaborators were trained to embrace best practices in processing "clean data," which requires adherence to consistent application of clearly defined procedures and norms for the data processing with minimal errors. Initially, Freedom Narratives used Kora as a backend system, an open-source, databasedriven, online digital repository, and content management application for complex multimedia objects developed at the Matrix Center for Digital Humanities and Social Sciences at Michigan State University. ${ }^{26}$ For the curation of the data, a combination of software was used, including Google Drive, Google Documents, Microsoft Excel, and Adobe Acrobat Pro DC. Matrix contributed to phase one and the proof-of-concept public website (launched in December 2018), showcasing the realistic capabilities of this research project and data within. During phase one, all data were entered offline on Excel sheets and were manually sent to Matrix's team of programmers, who were responsible for uploading the data to the backend to make it available online. In May 2019, the project commenced phase two, welcoming Kartikay Chadha as the new developer for the backend and frontend of the project. Following the analogue best practices of Freedom Narratives, Chadha developed a new customized version of the Web Portal, which was initially designed as a content management web application for the Language of Marks project. ${ }^{27}$ This new version of the Web Portal allows the creation of databases using Structured Query Language (MySQL) and is completely customized to Freedom Narratives methodologies with a user-friendly interactive platform employing novel algorithms to collect, store, organize, analyze, meta-tag,

25 Anitta Lucchesi and Richard Legay, "Learning by Doing: Introducing Students to Public History through Digital Projects," International Public History 2-1 (2019).

26 Center for Digital Humanities \& Social Sciences - Matrix, Kora, https:// kora.matrix.msu.edu/promo_index.php (accessed 5 June 2021).

27 Kartikay, Keefer, and Ladly, http://decodingorigins.org/decodingoriginsindex/home/index.php. 
and cross reference data to generate meaningful information as biographies, in this case. ${ }^{28}$

The development of this Web Portal employed user-sensitive and iterative learning design methodologies to create an intuitive web interface that immensely improved data processing efficiency and saved time. These methodologies enabled a front-end interface to bridge the gap between technology and digital data organization/management protocols. The Web Portal enforces analogue methods of data reorganization that cater to Freedom Narratives. The "reorganization" of data consists of the extraction of data from digital copies of original sources and organizes them into a relational format, i.e., rows and columns. Instead of alteration between documents, the Web Portal allows researchers to link PDF documentation and corresponding work with controlled vocabularies that are simultaneously displayed on one screen. The "Source" tab of the Web Portal records the metadata of multiple digital files that are being processed. The Freedom Narratives project leverages the applications of growing computer science technology to extract meaningful information from raw digital data sources. The biographies that are created are not only the representation of data but also interpretations, to some extent, allowing user audiences to understand the lives of individuals.

The project's approach to developing best practices to deal with big data is to first connect the details of the sources to each specific event recorded on the website. The visual source presentation is standardized, so users can access the exact passages which are relevant to each specific individual. The full document, including the complete metadata of the original documentation, is also linked to the person's biography. For each event entered, a cropped version of the full source is displayed with a red square around the area where the exact information is located. The full source is also connected to the cropped ones and displayed for users to view. However, inside of an individual entry, "cropped versions" can be found alongside the metadata. The intention of this visual presentation is not only to offer to the user proof of the data entered, but also to make as many sources available as possible, including ones that are not available online in another platform or cannot be easily accessed (see Figure 1).

Considering issues such as the ownership of data and the ethics of data collection, Freedom Narratives records information in meta-fields for both the physical and the digital copy of the source. Each source has complete information for the "Original Source Meta-Data" relating to the fields informing where the original physical version is located (Source Type; Author or

${ }^{28}$ Kartikay Chadha, Katrina Keefer, and Martha Ladly, "Decoding Origins Web Portal: Creating a Visual Database with Archival Sources from the Era of African Slavery," in Lovejoy, Paul E., Lovejoy, Henry B., Chadha, Kartikay, and Melek Delgado, Érika (eds.), Regenerated Identities - Documenting African Lives; and http://www. decodingoriginswebportal.org/\#2 (accessed 5 June 2021). 
Figure 1. Digital Identity of Bosseo - FN000600 - Personal data and example of one of the sources used in his entry.

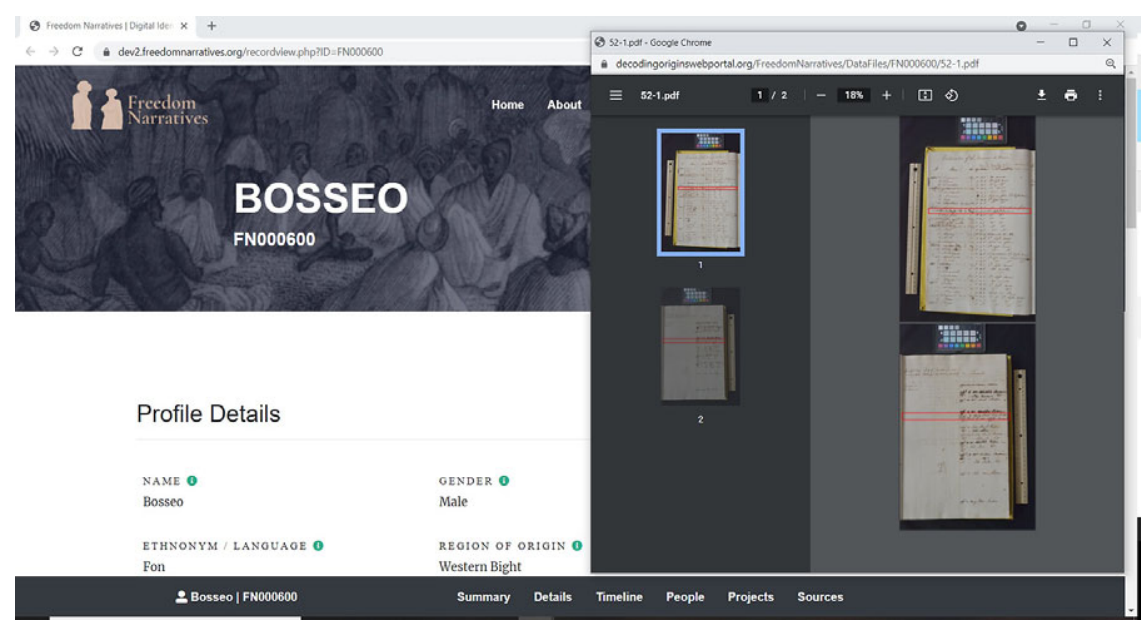

Creator; Title; Date; Archive/Organization; Accession number; Publisher; Place and Date of Publication) and to "Digitized Source Meta-Data" (Digitized by Organization/Archive; Researcher responsible for Digitization; Digitized Title; Date of Digitization; Page or Folio Number; Description; Copyright Management). The Freedom Narratives public website follows strict copyright guidelines for online publication of original sources, digital files, and associated internal or external metadata. Both physical and digital metadata are necessary for the online display of the source, as the digitized document "is not, at its material level, the original version, but rather a copy of it rendered in a new medium of bits and bytes, data and code," and therefore cannot be understood as the same item. ${ }^{29}$

The purpose of this description is to discuss the best practices that have been adopted in the development of the database and public website. For Freedom Narratives, best practices adhere to explanations of how the project has been developed, by whom, and according to what standards. The website acknowledges the project team, its direction, management, technical coordination, collaborators, researchers, and financial assistance. The description of best practices explains the methodology, the use of controlled vocabularies, definitions, and the relevant citations. The fundamental building blocks are the controlled vocabularies, conceived and created in four languages (English, French, Portuguese, and Spanish), with the terms to describe and present data carefully defined and applied in the organization of data.

29 Michael J. Kramer, “Going Meta on Metadata,” Journal of Digital Humanities 2-3 (2014). 
The development of Freedom Narratives, therefore, is a major step forward in the organization of materials for open access and analysis of the personal lives of individuals caught in the nexus of slavery and the slave trade. For this, the project associates with researchers around the world who wish to be part of database construction and who see Freedom Narratives as a trustworthy platform for the publication of data. As the project focuses on West Africa, every historian who has data on the life of people born in this part of the continent can be part of Freedom Narratives as a collaborator. For every individual recorded in our database, a collaborator is associated with its data, as is the name of the person who entered the data. Freedom Narratives aims to give all collaborators and our team recognition. For collaborators who share large amounts of data identified as a "collection" with Freedom Narratives, a dedicated space on the database and public website is allotted where their data are available for both public and/or restricted access along with an introduction. In the advanced search, a user will also have the possibility to search via collections, even if the collections do not have a homogeneous topic.

The database and website also include materials already public on other websites as there are overlapping categories of sources: 1) published materials on individuals from travel accounts, missionary narratives, and other sources; 2) documentation on Liberated Africans, especially from the Sierra Leone Public Archives, which has also been shared with Liberated Africans (www.liberatedafricans.org) and Language of Marks (www.languageofmarks. org); 3) fugitive slave advertisements from Brazil, the French islands in the Caribbean, Jamaica, and North America, which are housed on separate websites, initially focused on Le Marronnage dans le Monde Atlantique (www. remparts.info/marronnage_2-0/fr/index.html); and 4) baptismal, marriage records, memorials, military service documents, petitions, and other materials from the Slave Societies Digital Archive (www.slavesocieties.org) that can be used to reconstruct life stories in Spanish and Portuguese territories where published accounts are often lacking. Those websites are collaborators whose data are extracted from their platforms and indicated as such in the data entry. For open-source databases the unique identifying numbers (if they exist) for their entries are recorded to enable direct external hyperlink connection to these projects. In conclusion, all materials and metadata in Freedom Narratives are examined by the two directors, and when different opinions and interpretations emerge, they are discussed more widely to reach consensus among experts in the collaborating team.

\section{A Database Centered on Life Narratives: Methodology of Entering Data}

\section{Person}

The basic structure of data management is based on four interrelated methods of identification, first establishing the "Person" as a unique 
individual, then examining the various known "Events" in that person's life, the "Geographical Details" where such events occurred, and the "Sources" from where this information came. These four dimensions of management are organized digitally as an open-source relational database that forms the basis of the website. The "Person ID" entry is a project-generated unique identifier for each case file entered in the Freedom Narratives database, called "FN ID." These identifiers follow the same format: FN, followed by six digits (e.g., FN001555), allowing distinctions among individuals who have the same name or no name or even lacking other personal information. Each researcher creates a file for the person on the Web Portal, which is reviewed and approved by the directors before online publication. Only the directors and the administrator of the Web Portal have access to all entries.

Controlled vocabularies are used to enable the development of a database that allows analysis of patterns and facilitates interpretation. The controlled vocabularies are in Portuguese, Spanish, French, and English and consider particularities of each historical and language context. The search engine includes an expanded vocabulary in each language that accounts for nuances of meaning for words which have specific meanings in their historical contexts. These terms are linked to the controlled vocabulary to assist users, especially non-academics, in obtaining information. The variations in terms are not visible to users, as the frontend of the website presents only controlled vocabulary, but nuances are tagged in the backend.

The controlled vocabulary is simple in some cases, such as in identifying gender (Unknown; Female; Male). In other cases, the controlled vocabulary is relatively more straightforward, such as "Physical Descriptions" (None Specified; Blind Partially; Blind Totally; Body Parts Missing; Body Piercing; Branding; Bruise or Wound; Complexion Dark; Complexion Red; Complexion Yellowish; Deaf; Dental; Hair Style; Height Short; Height Tall; Illness Sign; Lameness; Moustache; Mute; Pregnant; Scarification; Smallpox; Tattoo; Weight Heavy; Weight Skinny). Other controlled vocabulary is based on the context of the subject, such as for "Age Category." It is necessary to highlight again that Freedom Narratives does not deal with "slaves," but with people who once were enslaved or who might still be. Therefore, in the case of age classifications, the age recorded, even if stated in the source, can be fuzzy. In our controlled vocabulary, a person can be an "Infant," "Child," "Adult," or "Old Person." The meaning of each category is based on a historical understanding of these classifications, but not on the commercial transatlantic slave trade classification. Therefore, the category of a "Child," for instance, consists of anyone aged 3 to 13 years old. However, it is necessary to highlight that an enslaved child is described in most of the sources through a classification based on height ( 4 feet 4 inches for the British traders, and 3 feet or quatros palmos for Portuguese trades for example). ${ }^{30}$ For

30 Melek Delgado, "Liberated African 'Children,"” 84-86; Melek Delgado, "Children, Childhood and Slavery," 60. 
"Ethnonym/Language," "Occupation," and other features, the details are more complex and are expanded as new identifications are discovered.

The "Name" is the first information entered for an FN profile. The record of names is entered under "Person." The name of the individual is recorded as it is reported in the primary source, or as it is in the academic work on which the entry is based. There are two fields to enter names: "Name" and "Alternative Names." When possible, the African name of the individual is used and recorded under "Name." If this is not possible, the most common name is used, including every part of the name as it is written in the source: given/first name, surname/last name (e.g., André do Amaral). If the primary sources do not mention the individual's name, the person is described as "Unknown." As is common in these data, individuals are referred to by more than one name. "Alternative Names" can be name variations, nicknames, aliases, married/maiden names, assumed names, variant spellings of African and Christian names, alternative spellings with abbreviations or initials, and several other things. A semicolon ( ; ) is used to differentiate multiple entries in various fields of the Web Portal unless a multiple select HTML type field is provided.

In a key divergence from other projects, Freedom Narratives does not use the concept of surname. This project acknowledges that surnames are a Eurocentric concept rooted in the Judeo-Christian tradition and do not reflect the reality of the group of people whose biographies are recorded. The use of surnames did not exist among Africans prior to their conversion to Christianity. Furthermore, their use for recording enslaved Muslim African names is incongruent with Muslim naming practices and can lead to the misnaming of individuals. In the case of ecclesiastical records in Portuguese and Spanish colonial settings, surnames were not generally recorded, as the use of surnames was a practice among the free population of European and mixed descent. Spanish practice used the surnames of both the father and mother, with the father's surname usually coming first, while the opposite happened in Portuguese practice, where the mother's name comes first.

This is not to say that surnames are not relevant or cannot be usefully included in the database. Fugitive slaves, for example, could be referred to by their owner's name, and those enslaved Africans who reached freedom in the Americas sometimes adopted their former owner's names. However, this brief explanation aims to clarify that the concept of surnames is largely irrelevant to diverse data where very few were born and baptized under a Christian/Judaic tradition. The record of the surname is entered under the field "Name," where the full name is recorded. The project aims to not incur the mistake of identifying any other name that came after the first name as a surname, especially if these are not Christian names. When searching the website, all the names and variants are searchable with no need for the distinction of "First Name" and "Surname" categories.

Names can offer evidence relevant to identities when they can be associated to other factors like religion, as with Muslim names. In the case of 
Akan, names can be days of the week or can have special meanings in other cultures. The direct association of names to specific ethnic groups can lead to mistakes, as the method of analysis can be valid for some cases but cannot be totally certain. ${ }^{31}$ Freedom Narratives is careful in the use of this approach. The main reason is because most sources used for life narratives were produced by third parties who often could not speak the language of the subject and did not know the cultural practices they were recording, which often led to the mispronunciation of names and attempts at phonetic spelling in the sources. The direct relationship of the information recorded to specific cultures and societies - and, consequently, to ethnicity - is considered a difficult area, to which the project dedicates considerable attention.

Another significant point that needs to be addressed is the use of the term "ethnonym" instead of "ethnicity." The decision for Freedom Narratives is to use "Ethnonym/Language" instead of ethnicity because the meaning of ethnicity itself is situational and hence problematic. ${ }^{32}$ Most of the time when terms such as "ethnicity," "tribe," "nation," etc. are used in the sources, the reference is to language. Furthermore, many sources suggest that an individual could speak only one language, when, in most cases, people could speak at least two - and often quite a few - languages. Ali Eisami, who came from Borno, spoke Kanuri but almost certainly spoke some Hausa, and he lived in the Oyo capital for at least five years and therefore had to have known Yoruba; further, he learned English in Sierra Leone, which, according to the linguist Sigismund Koelle, was far from perfect. ${ }^{33}$ Therefore, the reason for referring to "Ethnonym/Language" is because it is usually not possible to know what the sources mean in assigning a supposed ethnicity.

A further problem in referring to ethnicity is how this concept was understood in the diaspora. Uses of ethnic classifications in the Americas and in Africa are not equivalent. Many terms, such as "nation" or "country," were used in the Americas to indicate ethnicity. However, it is known that such designations of ethnicity did not always conflate with a language, and it was not always the case that someone was from a specific group only because they understood or even spoke the same language, if language was a factor. As such, "ethnic" terms in the Americas, such as Lucumí in Cuba, Mandingo/ Mandinga, Angola, and Congo, were wide classifications that do not

31 Hence, the project disagrees with the approach in "African Names Database" of David Eltis, Martin Halbert, Philip Misevich, G. Ugo Nwokeji, and David Eltis; see G. Ugo Nwokeji and David Eltis, "Characteristics of Captives Leaving the Cameroons for the Americas, 1822-37," Journal of African History 43-2 (2002), 191-210, and www.african-origins.org (accessed 5 June 2021).

32 Paul E. Lovejoy, "Methodology through the Ethnic Lens," in Falola, Toyin and Jennings, Christian (eds.), Sources and Methods in African History: Spoken, Written, Unearthed (Rochester: University of Rochester Press, 2003), 110; and Paul E. Lovejoy, Slavery in the Global Diaspora of Africa (London: Routledge, 2016), 201-202.

33 Lovejoy, "Ali Eisami," 131-132. 
correspond with identifications in Africa. Because historians have debated the meaning of ethnicity in recent years, the project has had to accommodate the possibility that when individuals were interviewed, they responded using a specific language because this was the language used to question them, not necessarily because this was their mother tongue. ${ }^{34}$ Henry B. Lovejoy draws attention to the term "Lucumí," which did not necessarily refer only to Yoruba in Cuba; indeed, the term was repeatedly hyphenated with other ethnolinguistic terminology in sources in a way that implies a broader correlation. ${ }^{35}$ What is understood is that they could speak Yoruba, but by no means were they necessarily fluent in Yoruba, nor was it their mother tongue.

Freedom Narratives deals with these broad categories with a field named "Ethnonym/Meta-Ethnic." When entering data under "Person" the researcher inputs information in the "Ethnonym/Meta-Ethnic" and "Ethnonym/Language" fields. For recording data, the project uses a controlled vocabulary for both fields, while the researcher is also asked to enter how the term is referred to in the source under the field "Ethnonym/ Language in Original" (e.g., Poullar, Fula, Peul, Fulani, etc.). The database contains all variations of the term in the sources. Consequently, Freedom Narratives is producing a valuable secondary record on ethnonyms, an evergrowing list, which contains controlled vocabulary terminology, variations of ethnonyms in primary sources, and links to region of origin (e.g., Fulbe | Poullar; Pualard; | Western Savanna). The terms relate to variations and location based on a diversity of primary sources and changes through time, as the entry of these data in an individual's folder is tagged with the metadata of the source and when the event took place. This gathering of data can also help researchers who cannot identify where an individual was born but where an "Ethnonym/Language" can establish an approximate location (e.g., FNXXXX is identified as Allada, and their "Region of Origin" would be the controlled vocabulary "Western Bight" since Allada

34 Gwendolyn Midlo Hall, Slavery and African Ethnicities in the Americas: Restoring the Links (Chapel Hill: University of North Carolina Press, 2005). Also see Paul E. Lovejoy, "The African Diaspora: Revisionist Interpretations of Ethnicity, Culture and Religion under Slavery," Studies in the World History of Slavery, Abolition and Emancipation 2-1 (http://www2.h-et.msu.edu/ slavery/essays/esy9701love.html); Paul E. Lovejoy and David V. Trotman (eds.), Trans-Atlantic Dimensions of Ethnicity in the African Diaspora (London: Continuum, 2004); Paul E. Lovejoy, "Transatlantic Transformations: The Origins and Identities of Africans in the Americas," in Sansone, Livio, Soumonni, Elisée, and Barry, Boubacar (eds.), Africa, Brazil, and the Construction of Trans-Atlantic Black Identities (Trenton: Africa World Press, 2008), 81-112; Robin Law, "Ethnicities of Enslaved Africans in the Diaspora: On the Meanings of 'Mina' (Again)," History in Africa 32 (2005), 247-267.

${ }^{35}$ I wish to thank Henry B. Lovejoy for a discussion of the difficulty of Lucumí identification. Also see www.liberatedafricans.org (accessed 5 June 2021). 
are people from the interior of the Bight of Benin). Equally, if the primary source mentions language, the project also captures the languages the person could read (and sometimes write) under "Literacy - Language," choosing from a controlled vocabulary.

\section{Event}

The "Event" entry is the main body of data for the project. Without information on life events, a person is not eligible to be added into the database. For each person, at least five events are required to be identified to be included in the database of the project. "Event Type" is a category that captures all events that are possible to extract from primary sources. "Event Type" is organized under a controlled vocabulary list. Some events would be obvious to enter, such as "Enslavement." Others require more reflection; for example, if an enslaved person recorded in a court case in Brazil is referred to by a Portuguese name, it can be assumed that there was a "Baptism" event at some point in the individual's personal history, which had to have taken place before the event "Legal Proceeding," a term which incapsulates all events related to legal issues, such as going to court. Hence, when the events are entered on the Web Portal it is necessary to make a clear distinction if the specific event and date are written in the primary source, by informing "Yes" or "No" under the fields "Imputed Date," "Circa Period," "Imputed Data," and "Imputed Data by External Researcher." Each of these fields has a different meaning, and the aim is to present to the user the most honest and clear understanding of which details in the database are imputed and which are not. "Imputed Date" and "Circa Period" are related to information about the time of the event. "Imputed Date" is used if a date is be inferred by the researcher entering the data. If a specific date cannot be determined but a range of years ("Circa Period") can be, this information is entered. "Imputed Data" is related to the imputed event, as in the case of "Baptism" in the previous example. The field "Imputed Data by External Researcher" is used when the data entered are not recorded directly from a primary source but are the result of a scholarly conclusion published in an article, book, or database. These data are entered as an event, and the metadata for the bibliography is recorded for the event. The Web Portal enables both automatized chronological and manual reordering of the events at any point of time during data curation.

During the identification of an event, the field "Event Description" records any extra information about the specific event, which other fields cannot capture. It is a searchable field, where users can find extra information about the event. There is no controlled vocabulary defined for this field as it is a summary that captures a single event to clarify the purpose of the event or if something specific happened during an event. For example, a "Resistance - Against the State/Authority in Power" event could mean the individual ran away from the master, started a rebellion, or refused to work, 
and hence might require further clarification. This field can bring extra information about the person, e.g., if, in this case, the person ran away at night with some specific tools or food.

Freedom Narratives allows the different kinds of relationships that individuals experienced during their lives to be recorded. The field to record kinship is under the "Person" section on the Web Portal. This allows for the recoding of family relationships, even if unconnected directly to an event. All other types of relationships need to be connected to an event. All terms for various types of relationships are pre-entered according to the controlled vocabulary list. The project captures as much information as possible; therefore, there are two methods to record relationships. The first is between two people who are both recorded in the database, and the second is between a person who is part of the database with an individual who is not in the database for lack of adequate information. For those who are part of the database, the relationship is created by tagging the person, using his or her FN number. The Web Portal provides a visual interface to perform this task using HTML5 dropdown menu and Java Script search functionalities. In cases where the relationship is with someone who is not part of the database because he or she was born outside West Africa, or where there is not enough information for the details to be included in the database, the relationship only includes name and the kind of relationship they had.

The "Event Identifier" is a unique reference number that identifies more than one entry to the same event. This identifier provides connections between more than one person who participated in the same event. This event ID connects people even if they did not have a direct relationship, or if a relationship is not clear from the sources. This tool is used to record all people who experienced the same event, such as the "Embarkation" on a specific vessel or large-scale events, as with all West African people who, for example, were in Brazil at the time of the abolition of slavery in 1888. All events are connected to sources on the Web Portal and to all metadata. Therefore, the user can query all the sources that refer to a specific event. The "Event" field also brings information on the "Occupation" the person had in each event during his or her life, which is also based on the controlled vocabulary.

\section{Geographical Area}

Freedom Narratives focuses on West Africa, but other regions of Africa and areas of the world are also relevant for the project since, in many cases, people left West Africa almost always after enslavement. Out of necessity to spatially locate different events during an extensive period (four hundred years), the project divided the world map into sub-regions. The various sub-regions that have been created and identified apply to our methodology of best practices in entering data through controlled vocabulary. Data from these sub-regions are inputted in three different points of data entry. When entering personal 
data, the "Region of Origin" field is used for the sub-region where the person came from, usually identified with the area where the person was born. Secondly, sub-region data are entered for "Region of Final Destination," which is understood as the last region where information on the person was documented. This could record the region where they died but could also be the last place for which there is recorded information about the person. Finally, a sub-region is entered for each "life event" recorded in the database. Each event happened in a geographical area. In this case, the regions of those events could have happened in any part of the world.

The methodology for recording geographical areas in the project enabled the creation of vast metadata related to different macro and micro scales based on physical areas. The process of entering geographical data in relation to an event is initially recorded based on a controlled vocabulary that asks the researcher to classify the place they want to record as "Unknown," "Continent," "Region" (i.e., the controlled vocabulary used for all subregions), and as "Province/Colony/Dependency/Emirate," "Country/ State," "City/Town/Village," or "Location." Given the lack of space to explain all the possibilities of data recording, it is significant to clarify that, when a geographic area is entered in the Web Portaland its data are recorded, there is no necessity to enter the associated details again. The same is true regarding the relationship of the place to other locations. The lowest level is what we call "Location" with a controlled vocabulary related to geographical spaces - e.g., "River," "Church," "School," "Cemetery," "Hospital," etc. Historical images of "Locations" and "City/Town/Village" can be added in the metadata of each geographical area. All these locations are tied to a "City/Town/Village" which require all details to be filled out but only once. For instance, when Kano is entered for the first time in the Web Portal, all details are recorded for all "Locations" that can be related to this city. The same is true for all other places and geographic designations. "Africa" is entered into the system, and all sub-regions and, consequently, all cities, colonies, countries, and so on are already entered. If a location is not associated with a "City/Town/Village," such as a river, lake, or mountain, the form jumps past "City/Town/Village" to other details. Coordinates are only recorded for "Location" and "City/ Town/Village."

Events are tagged to geographical areas, which in most cases are already recorded in the system. The hierarchy of the data entry is related to the place the researcher wants to record. Moreover, if details are lacking then it finds the first level that is known. If only the "Region" is known, then the region is selected. All other details are automatic. This automation helps researchers to enter data with which they are not familiar. This form also captures alternate spellings a place might have. For instance, "Borno" recognizes the variations found in sources such as "Bornu; Bournou; Bornouh." The names and locations of places are also connected to modern places and contemporary countries. Therefore, a large set of data related exclusively to specific locations, along with variations of names for all geographical 
coordinates, are in the database, thus enabling the mapping of a person's movements.

The geographical template used by the project adheres to the whole African continent as published in History in Africa. ${ }^{36}$ As Freedom Narratives concentrates on people born in West Africa, the nine sub-regions that are most relevant to the project include Central Savanna, Western Savanna, Rivers, Forests, Voltaic, Western Bight, Eastern Bight, Cabo Verde, and Gulf Islands. ${ }^{37}$ The geographic organization of the continent revises and extends the geographical division used by Philip D. Curtin in The Atlantic Slave Trade: A Census and, subsequently, in Slave Voyages. ${ }^{38}$ Slave Voyages focuses on slave vessel voyages, and its division of Africa based on Curtin's schema follows coastal areas of slave vessel departure. These areas of embarkation, despite having been used by many historians, were created from the perspective of slave traders and not from the effort to identify where enslaved persons came. The identified sub-regions use a term that cannot be mistaken with a modern country or a European colony, and no sub-region has a border that is the same as modern or colonial geographical boundaries. Its main methodological concern takes into consideration geographical factors, climate issues, historical patterns (the period of the slave trade from the sixteenth to the nineteenth century), and political changes during these four centuries.

Sub-regions are a necessary identifier for entering of data, and they provide the basic classification for a geographical area. By using sub-region data, large-scale analysis can be performed, for instance, on the representation of movement of people during specific periods or through the whole extent of years recorded in the project. Furthermore, the use of sub-regions specifies specific locations that are not necessarily included in the documentation, whether a person's area of origin can only be identified by the data related to ethnonyms or language. As the database is formed by life events, the record of an event for each person needs to be connected to geographical details, which, for instance, can be connected to a broad classification of a sub-region or to a narrow location such as a market in a town. If a person came from a border area between two sub-regions, then both sub-regions are identified for the geographical details. In these cases, the intention is not to infer only one of the two areas. It is impossible to determine one of the

36 See Henry B. Lovejoy et al., "Redefining African Regions for Linking OpenSource Data," History in Africa 46 (2019), 5-36; and the revised updated version, Henry B. Lovejoy et al., "Defining Regions of Pre-Colonial Africa: A Controlled Vocabulary for Linking Open-Source Data in Digital History Projects," History in Africa 48 (2021), $1-25$.

37 For a detailed explanation of the borders of each sub-region, see Henry B. Lovejoy et al., "Defining Regions of Pre-Colonial Africa."

38 Philip D. Curtin, The Atlantic Slave Trade: A Census (Madison: University of Wisconsin Press, 1969) and http://www.slavevoyages.org/ (accessed 5 June 2021). 
sub-regions and, for the purposes of searching the database, both areas will be searchable. The imprecision of some of the borderlines between these subregions is a significant historical factor. One of the aims of the database is to represent the variety of movement between and among sub-regions through several means, allowing for the recognition of more specific places, the trade routes cross West Africa, and further considerations.

The use of mapping is important because the project is not focused solely on the areas of embarkation of people, but also on where people came from and their subsequent movements. It is relevant if a large number of the people in the database had experienced slavery and had embarked at a slave port on the African coast. However, the region where a person was born and their experience on the African continent and beyond cannot be related only to their enslaved identity at the time of departure from Africa but on all known events.

\section{Conclusion}

"Data mining" is a process of extracting "hidden patterns from huge amounts of data," followed by "topic modelling" algorithms to uncover hidden thematic structures in collections, and, consequently, developing new habits of searching and browsing - hence doing research. ${ }^{39}$ The first step is to preprocess raw data, the second to mine the data, and the third to interpret the results. The reality of our time is computers can do a lot of the work, but the historian behind all these phases still provides the most essential input. ${ }^{40}$ The role played by the historian in the construction of a database is central, as the methodological approach the scholar takes in assessing the sources determines data entry and the aim of the project. Critics of Digital Humanities that deal with people of African descent claim that new practices are required for examining documents related to slavery. ${ }^{41}$ It is fundamental to address the bias behind the production of documents, although it is also essential that historians criticize their own methods in engaging with slavery sources to challenge dehumanizing impulses. ${ }^{42}$ The need to organize databases with biometric, death, and violence information, for instance, cannot undermine the humanity behind the data. A new methodology is necessary, one that is "attuned to black life and to dismantling the methods" that enumerate, commodify, and calculate bodies that can become neutralized by the

39 Pelle, "Himalaya of Data," 13.

40 Pelle, "Himalaya of Data," 13.

41 Kim Gallon, "Making a Case for the Black Digital Humanities," in Klein, Lauren F. and Gold, Matthew K. (eds.), Debates in the Digital Humanities 2016 (Minneapolis: University of Minnesota Press, 2016).

42 Roopika Risam and Kelly Baker Josephs (eds.), The Digital Black Atlantic (Minneapolis: University of Minnesota Press, 2021). 
historical approach of large databases. ${ }^{43}$ As proposed by Jessica Johnson, digital practices relating to people of African descent are "the interface by which black freedom struggles challenge reproduction of black death and commodification, countering the presumed neutrality of the digital." ${ }^{4}$

Since the beginning of the project two main issues have influenced the design of the Freedom Narratives path: first, the false idea of digital literacy around the world; and second, the lack of access to the internet, and thus the impossibility to engage with all the possibilities offered by these projects during our digital age. The website is being developed under "user sensitive inclusive design," taking into consideration "design thinking" to produce a user-friendly tool. ${ }^{45}$ The project is producing manuals (written and in video) to assist the navigation of the website as support material to target inclusion in digital literacy.

The accessibility of our data to communities that cannot gain online access is one the parameters of the project. Since its inception, Freedom Narratives has sought to be able to run offline as well as to present updated versions from time to time. One approach is to export the backend SQL for transport on physical hard drives. Another is converting SQL or CSV to JSON files using python, which can be used to build static websites in Jekyll. Once the JSON data file is given to Jekyll, it builds the static website using the data file and other supporting codes. The static version is then self-contained that is, it is unable to alter data until the rebuilt codes runs with Jekyll. These solutions are for access issues in places with low bandwidth internet.

Aware that large parts of our data come from diverse archives in Africa, the Caribbean, Latin America, and other countries in the Global South, the project intends to distribute offline versions of the platform when the access to the internet is limited or not possible. ${ }^{46}$ The offline copies can be sent to archives and universities. The idea is to have the research engine available to users who are accessing the physical archives but can use relational data instead of using physical copies (when possible) - thus promoting access to the work possible in those archives to a wider public. Freedom Narratives recognizes that local archives can be invisible in the process of data collection for the creation of databases, as these practices can follow imperial practices and potentially violent negligence of local rights. The recognition of the

43 Jessica Marie Johnson, "Markup Bodies. Black [Life] Studies and Slavery [Death] Studies at the Digital Crossroads," Social Text 36-4 (2018), 65.

44 Johnson, "Markup Bodies," 58-59.

45 Pietro Micheli et al., "Doing Design Thinking: Conceptual Review, Synthesis, and Research Agenda," International Journal of Information Management 36-2 (2019), 124-148; Alan F. Newell and Peter Gregor, "User Sensitive Inclusive Design,” JIM 2001 Interaction Homme/Machine E्E Assistance, 4-6 July, France (2001), 1-4.

${ }^{46}$ For discussion of the massive digitalization of African archives, see Fabienne Chamelot, Vincent Hiribarren, and Marie Rodet, "Archives, the Digital Turn, and Governance in Africa," History in Africa 46 (2019), 1-18. 
source's origin is vital. Archival policy is followed with respect to all projects. Given the archives that Freedom Narratives cooperates with directly, a collaborative interaction based on the exchange of techniques with the local archive and scholarly staff is established, including training, provision of equipment, and creation of websites. Hard drive copies of all digitized materials are made accessible.

In conclusion, Freedom Narratives deals with a very old question of Africa and diaspora history. Who were those who had their lives marked, interrupted, or ended by the actions of the transatlantic slave trade? Despite these being old queries, only now with the development of Digital Humanities and the possibility to gather scattered and diverse sources in one place can these inquires start to be answered. Freedom Narratives is a digital platform where the main body of sources are organized in a digital repository to bring light to these issues. The project wishes not only to be a tool for academics but, at the same level, to also become a tool for the use of the general public, as these diasporic accounts recount the direct experience of natal alienation as opposed to subjugation through the memory of the Middle Passage and what had been retained about the homeland.

\section{References}

Anderson, Richard and Henry B. Lovejoy (eds.), Liberated Africans and the Abolition of the Slave Trade, 1807-1896 (Rochester: University of Rochester Press, 2020).

Chadha, Kartikay, Katrina Keefer, and Martha Ladly, "Decoding Origins Web Portal: Creating a Visual Database with Archival Sources from the Era of African Slavery," in Lovejoy, Paul E., Lovejoy, Henry B., Chadha, Kartikay, and Melek Delgado, Erika (eds.), Regenerated Identities - Documenting African Lives.

Chamelot, Fabienne, Vincent Hiribarren, and Marie Rodet, "Archives, the Digital Turn, and Governance in Africa," History in Africa 47 (2020), 101-118.

Curtin, Philip D., The Atlantic Slave Trade: A Census (Madison: University of Wisconsin Press, 1969).

Daddi Addoun, Yacine and Paul E. Lovejoy, "The Arabic Manuscript of Muhammad Kaba Saghanughu of Jamaica, c. 1820," in Paul, Annie (ed.), Creole Concerns: Essays in Honour of Kamau Brathwaite (Kingston: University of the West Indies Press, 2007).

Gallon, Kim, "Making a Case for the Black Digital Humanities," in Klein, Lauren F. and Gold, Matthew K. (eds.), Debates in the Digital Humanities 2016 (Minneapolis: University of Minnesota Press, 2016).

Gold, Matthew K. and Lauren F. Klein, Debates in the Digital Humanities 2016 (Minneapolis: University of Minnesota Press, 2016).

Hall, Gwendolyn Midlo, Slavery and African Ethnicities in the Americas: Restoring the Links (Chapel Hill: University of North Carolina Press, 2005).

Johnson, Jessica M., "Markup Bodies. Black [Life] Studies and Slavery [Death] Studies at the Digital Crossroads," Social Text 36-4 (2018), 57-79. 
Kramer, Michael J., "Going Meta on Metadata," Journal of Digital Humanities 2-3 (2014), http://journalofdigitalhumanities.org/3-2/going-meta-on-metadata/ \#to-going-meta-on-metadata-n-2, (accessed 5 June 2021).

Larson, Pier M., "Horrid Journeying: Narratives of Enslavement and the Global African Diaspora," Journal of World History 19-4 (2008), 431-464.

Law, Robin, "Ethnicities of Enslaved Africans in the Diaspora: On the Meanings of 'Mina' (Again)," History in Africa 32 (2005), 247-267.

Law, Robin and Paul E. Lovejoy, The Biography of Mahommah Gardo Baquaqua: His Passage from Slavery to Freedom in Africa and America (Princeton: Markus Wiener Publisher, 2008).

Lovejoy, Henry B., "The Register of Liberated Africans of the Havana Slave Trade Commission: Transcription Methodology and Statistical Analysis," African Economic History 38 (2010), 107-135.

Lovejoy, Henry B., Lovejoy, Paul E., Hawthorne, Walter, Alpers, Edward A., Candido, Mariana, Hopper, Matthew S., Lydon, Ghislaine, Kriger, Colleen E., and Thornton, John, "Defining Regions of Pre-Colonial Africa: A Controlled Vocabulary for Linking Open-Source Data in Digital History Projects," History in Africa 48 (2021), $1-25$.

Lovejoy, Henry B., Lovejoy, Paul E., Hawthorne, Walter, Alpers, Edward A., Candido, Mariana, and Hopper, Matthew S., "Redefining African Regions for Linking Open-Source Data," History in Africa 46 (2019), 5-36.

Lovejoy, Paul E., "The African Diaspora: Revisionist Interpretations of Ethnicity, Culture and Religion under Slavery," Studies in the World History of Slavery, Abolition and Emancipation 2-1 (1997).

- "Methodology through the Ethnic Lens," in Falola, Toyin and Jennings, Christian (eds.), Sources and Methods in African History: Spoken, Written, Unearthed (Rochester: University of Rochester Press, 2003).

_ - "Autobiography and Memory: Gustavus Vassa and the Abolition of the Slave Trade," Slavery and Abolition 27-3 (2006), 317-347.

_ "Transatlantic Transformations: The Origins and Identities of Africans in the Americas," in Sansone, Livio, Soumonni, Elisée, and Barry, Boubacar (eds.), Africa, Brazil, and the Construction of Trans-Atlantic Black Identities (Trenton: Africa World Press, 2008).

- "The African Background of Venture Smith," in Stewart, James B. (ed.), Venture Smith and the Business of Slavery and Freedom (Amherst: University of Massachusetts Press, 2009).

_, "Freedom Narratives of Transatlantic Slavery," Slavery and Abolition 32-1 (2011), 91-107.

- "Les origines de Catherine Mulgrave Zimmermann: considérations méthodologiques," Cahiers des Anneaux de la Mémoire 14 (2011), 247-263.

— Slavery in the Global Diaspora of Africa (London: Routledge, 2016).

_ Veteran," Millars (2017), 219-232.

, "Ali Eisami's Enslavement and Emancipation: The Trajectory of a Liberated African," in Anderson, Richard, and Lovejoy, Henry B. (eds.), Liberated Africans and the Abolition of the Slave Trade, 1807-1896 (Rochester: University of Rochester Press, 2020).

Lovejoy, Paul E., and David V. Trotman (eds.), Trans-Atlantic Dimensions of Ethnicity in the African Diaspora (London: Continuum, 2004). 
Lovejoy, Paul E., Érika Melek Delgado, and Kartikay Chadha, "Freedom Narratives of West Africans from Era of Slavery," in Lovejoy, Paul E., Lovejoy, Henry B., Chadha, Kartikay, and Melek Delgado, Erika (eds.), Regenerated Identities - Documenting African Lives (Trenton: Africa World Press, 2021).

Lovejoy, Paul E., Lovejoy, Henry B., Chadha, Kartikay, and Melek Delgado, Erika (eds.), Regenerated Identities - Documenting African Lives (Trenton: Africa World Press, 2021).

Lucchesi, Anitta, and Richard Lehay, "Learning by Doing: Introducing Students to Public History through Digital Projects," International Public History 2-1 (2019).

Melek Delgado, Érika, "Children, Childhood and Slavery in Sierra Leone: The Experiences of Liberated African Children, c.1808-1834,” PhD dissertation, University of Worcester (Worcester, UK, 2018).

_ 'Child' and 'Childhood,' 1808-1819," in Anderson, Richard and Lovejoy, Henry B. (eds.), Liberated Africans and the Abolition of the Slave Trade, 1807-1896 (Rochester: University of Rochester Press, 2020).

Micheli, Pietro, Wilner, Sarah J. S., Bhatti, Sabeen Hussain, Mura, Matteo, and Beverland, Michael B., "Doing Design Thinking: Conceptual Review, Synthesis, and Research Agenda," International Journal of Information Management 36-2 (2019), 124-148.

The National Archives of the UK, Foreign Office 315/31, Slaves Emancipated, 1829-1828.

Newell, Alan F., and Peter Gregor, "User Sensitive Inclusive Design," JIM 2001 Interaction Homme/Machine E Assistance, 4-6 July 2001, 1-4.

Nwokeji, Ugo G., and David Eltis, "Characteristics of Captives Leaving the Cameroons for the Americas, 1822-37," Journal of African History 43-2 (2002), 191-210.

Pelle, Snickars, "Himalaya of Data," International Journal of Communication 8 (2014), 2666-2678.

Risam, Roopika, and Kelly B. Josephs (eds.), The Digital Black Atlantic (Minneapolis: University of Minnesota Press, 2021).

Schwarz, Suzanne, "Reconstructing the Life Histories of Liberated Africans: Sierra Leone in the Early Nineteenth Century," History in Africa 39 (2012), 175-207.

_ , "The Impact of Liberated Africans 'Disposal' Policies in Early NineteenthCentury Sierra Leone," in Anderson, Richard and Lovejoy, Henry B. (eds.), Liberated Africans and the Abolition of the Slave Trade, 1807-1896 (Rochester: University of Rochester Press, 2020).

Sierra Leone Public Archives, Register of Liberated Africans, 1827-1829: 25,42330,708 .

SLPA, Liberated African Department Statement of Disposal, 1821-1833.

Theimer, Kate, "A Distinction Worth Exploring: 'Archives' and 'Digital Historical Representation,"” Journal of Digital Humanities 2-3 (2014).

Zaagsma, Gerben, "On Digital History,” BMGH - Low Countries Historical Review 128 (2013). 